\title{
The cholinergic immune regulation mediated by a novel muscarinic acetylcholine receptor through TNF pathway in oyster Crassostrea gigas
}

Zhaoqun Liu ${ }^{\text {acc }}$, Zhi Zhou ${ }^{\text {a }}$, Lingling Wang ${ }^{\text {b,* }}$, Wenjing Dong ${ }^{\text {a }}$, Limei Qiu ${ }^{\text {a }}$ Linsheng Song ${ }^{b, *}$

${ }^{a}$ Key Laboratory of Experimental Marine Biology, Institute of Oceanology, Chinese Academy of Sciences, Qingdao 266071, China

${ }^{\mathrm{b}}$ Key Laboratory of Mariculture \& Stock Enhancement in North China's Sea, Ministry of Agriculture, Dalian Ocean University, Dalian 116023, China.

${ }^{\mathrm{c}}$ University of Chinese Academy of Sciences, Beijing 100049, China

\section{Abstract}

Muscarinic receptors, which selectively take muscarine as their ligand, are critical for the immunological and physiological processes in animals. In the present study, the open region frame (ORF) of a homologue of muscarinic acetylcholine (ACh) receptor (mAChR) was amplified from oyster Crassostrea gigas (named as CgmAChR-1), whose full length was $1983 \mathrm{bp}$ and the protein it encoded contained 660 amino acids with a seven transmembrane region. Phylogeny analysis suggested that CgmAChR-1 shared homology with $\mathrm{M}_{5}$ muscarinic receptor found in invertebrates including Habropoda laboriosa, Acromyrmex echinatior and Echinococcus granulosus. After cell transfection of CgmAChR-1 into HEK293T cells 
and ACh incubation, the level of intracellular $\mathrm{Ca}^{2+}$ and cAMP increased significantly $(p<0.05)$. Such trend could be reverted with the addition of $\mathrm{M}_{3}$ and $\mathrm{M}_{5}$ muscarinic receptor antagonists DAMP and DAR. The CgmAChR-1 transcripts were ubiquitously detectable in seven different tissues with the maximal expression level in adductor muscle. When the oysters received LPS stimulation, CgmAChR-1 mRNA expression in haemocyte was increased to the highest level (6.05-fold, $p<0.05)$ at 24 h, while blocking CgmAChR-1 using receptor antagonists before LPS stimulation promoted the expression of oyster TNF, resulting in the increase of haemocyte apoptosis index. These results suggested that CgmAChR-1 was the key molecule in cholinergic neuroendocrine-immune system contributing to the regulation of TNF expression and apoptosis process.

Key words: Crassostrea gigas; Acetylcholine; Muscarinic acetylcholine receptor; TNF pathway; Immune regulation

\section{Introduction}

Acetylcholine (ACh), the neurotransmitter synthesized by choline acetyltransferase (ChAT) and hydrolyzed by acetylcholinesterase (AChE) with the products of choline and acetic acid ready for re-uptake and re-synthesis, is significant for cholinergic nervous system (Deiana et al., 2011). As the key molecule in cholinergic modulation, ACh takes part in many physiological functions in vertebrates, such as excitability, stress response and cortical modulation (Hurst et al., 
2013; Lucas-Meunier et al., 2003). It is demonstrated that ACh is critical for the immunomodulation in vertebrates (Norman et al., 2011; Rosas-Ballina and Tracey, 2009; Van der Zee et al., 2011). For example, ACh attenuates the synthesis of TNF and IL by human macrophages at the post-transcriptional stage (Borovikova et al., 2000). ACh released from the activated cholinergic nervous system of mammals can monitor the level of intracellular reactive oxygen species (ROS) by the cGMP-dependent protein kinase (PKG) pathway and the transactivation of epidermal growth factor receptors (EGFRs) (Krieg et al., 2004; Krieg et al., 2005; Wang et al., 1999). Being the first neurotransmitter ever defined (Kruse et al., 2012), ACh accomplishes its function by activating its receptors expressed on immune cells (Shi et al., 2014).

According to the relative affinities and sensitivities to different molecules, ACh receptors are classified into two major types, nicotinic ACh receptors (nAChRs) which have high affinity for nicotine, and muscarinic ACh receptors (mAChRs) which are particularly responsive to muscarine. The effects of mAChRs are mediated mainly by triggering the fluxes of intracellular second messengers $\left(\mathrm{Ca}^{2+}\right.$ and $\left.\mathrm{cAMP}\right)$ by activating the heterotrimeric $\mathrm{G}$ proteins (Dale, 1914). There are 5 subtypes $\left(\mathrm{M}_{1}-\mathrm{M}_{5}\right)$ of mAChRs in vertebrates, which could be subsequently characterized as two kinds. The $M_{1}, M_{3}$ and $M_{5}$ receptors have the preference for binding $G_{q / 11}$, activating phospholipase and inducing the increase of $\mathrm{Ca}^{2+}$ level. The $\mathrm{M}_{2}$ and $\mathrm{M}_{4}$ receptors inhibit the rise of adenylyl cyclase (AC) upon stimulation by binding to $G_{\mathrm{i} / \mathrm{o}}$, leading to down-production of cAMP (Hulme et al., 1990; Kawashima et al., 2012; Wess, 
1996). Vertebrate mAChRs are related to a series of physiological processes (MacDonald et al., 2015) including the modulation of immune function. CD11a could activate intracellular signaling pathways in $\mathrm{T}$ cells to increase $\left[\mathrm{Ca}^{2+}\right]_{\mathrm{i}}$, and cause the increase of the expression level of ChAT genes (Fujii et al., 2003). Furthermore, in the $\mathrm{M}_{1}$ mAChR gene-knockout mice model, $\mathrm{CD}^{+} \mathrm{T}$ cell differentiation was severely inhibited under stimulation (Zimring et al., 2005). These findings suggested that mAChRs were indispensable during the cholinergic immunomodulation in mammals.

However, the mAChRs in invertebrate are not well investigated, and most of the researches focus on limited species, such as locust and drosophila. For instance, mAChRs have been detected in the nerves of Drosophila melanogaster, Apis mellifera, and Manduca sexta (Aizono et al., 1997; Blake et al., 1993; Harrison et al., 1995; Van der Zee et al., 1992). Unlike vertebrates, mAChRs in invertebrates were found to modulate various nervous and non-nervous related processes (Caulfield and Birdsall, 1998). For example, release of transmitters are often inhibited by mAChs in the presynaptic sensory terminals (Trimmer, 1995), while the neuronal responses can be enhanced when postsynaptic mAChRs are activated (Caulfield and Birdsall, 1998). Nevertheless, compared with that in vertebrates, the mechanism of mAChR in cholinergic immunomodulation in invertebrates is still far from clear.

ACh and nAChRs have been previously reported to be existed in oyster Crassostrea gigas (Shi et al., 2014; Sun et al., 2014a), and the investigation about mAChR will benefit for the comprehensive understanding of the cholinergic neuroendocrine-immune system as well as the immunomodulation mechanism in 
marine invertebrates. The present study is conducted to (1) identify the G protein-coupled muscarinic receptor for ACh from oyster $C$. gigas (designated as CgmAChR-1), (2) investigate the fluctuation of intracellular $\mathrm{Ca}^{2+}$ and cAMP during the activation and inhibition of CgmAChR-1, (3) examine the phagocytosis rate and apoptosis index of oyster haemocytes, as well as the expression of CgTNFs after the activation of CgmAChR-1.

\section{Materials and Methods}

2.1. Oysters, antagonist incubation and LPS stimulation

Oysters C. gigas were collected from a breeding base in Qingdao, China. After drilling a tiny hole on the edge of the shell near the adductor muscle, oysters were put back into the tank and maintained at $18{ }^{\circ} \mathrm{C}$ for 14 days to get used to the new environment. Algae powder was added to the water every other day, and the seawater in the aquaria was replaced every day.

Five antagonists specific for $\mathrm{M}_{1}$ to $\mathrm{M}_{5}$ muscarinic receptors, PIR (pirenzepine, TOCRIS), AFDX (AF-DX 116, TOCRIS), DAMP (4-DAMP, TOCRIS), PD (PD102807, TOCRIS) and DAR (Darifenacin, Sigma) (Caulfield and Birdsall, 1998; Hulme et al., 1990), were employed in the antagonists incubation experiment. For example, in the CgmAChR+PIR group, one hundred microliter of $\mathrm{M}_{1}$ muscarinic receptor antagonist PIR was added into the cultured HEK293T cells before ACh treatment. The final concentration of each antagonist was $1.0 \mathrm{mmol} \mathrm{L}^{-1}$ in both cell transfection and adult injection experiments. 
112 LPS groups. In the LPS group, one hundred microliter of LPS $\left(0.5 \mathrm{mg} \mathrm{mL}^{-1}\right)$ from Escherichia coli 0111:B4 (Sigma) was injected through the tiny hole drilled on the edge of the shell, while oysters in the PBS group were treated with PBS (pH 7.4).

\subsection{Sample collection, RNA isolation and cDNA synthesis}

Fifteen were sampled at each time point after LPS stimulation as one replicate, and three replicates were taken for each test. The oysters in the blank group were collected at $0 \mathrm{~h}$ without any treatment. Hemolymph from each oyster was collected from the blood sinus and centrifuged at $800 \mathrm{~g}$ to gather haemocytes for RNA extraction. The serum was also harvested for the determination of the activities of immune-related enzymes. Five oysters were sampled as one parallel, and we did three parallels for each test.

Seven different kinds of tissues, such as haemocytes, gonad, mantle, gill, kidney, adductor muscle and hepatopancreas were also collected for the tissue distribution analysis. Tissues from 3 oysters were sampled as one parallel, and we did three parallels for each test. Then we extracted total RNA from haemocytes and tissues using Trizol reagent (Invitrogen, USA). The cDNA library was constructed using Promega M-MLV kit, and diluted to 1:40 for the subsequent experiments.

\subsection{Gene cloning and sequence analysis}

The ORF of CgmAChR-1 (CGI_10014948, EKC34110.1), which was 
homologous to vertebrate mAChR, was obtained and analyzed. The Expert Protein Analysis System was applied in the amino acid analysis. The protein domain was predicted with SMART software. Multiple alignment of the CgmAChR-1 with muscarinic receptors from other species was employed by the ClustalW software. Phylogenetic tree of mAChRs was built by MEGA software using neighbor-joining (NJ) algorithm.

\subsection{Cell transfection, drug treatment and second messenger determination}

HEK293T cells were cultured as described by Liu et al (Liu et al., 2015a). The full length sequence of CgmAChR-1 was amplified with corresponding primers and sub-cloned into the pEASY-M $\mathrm{M}_{1}$ expression vector (TransGene), designating as pEASY-M - -CgmAChR-1 plasmid. When the cell coverage ratio reached $60 \sim 80 \%$ in the wells, the recombinant plasmid was transfected with Lipofectamine LTX and Plus $^{\mathrm{TM}}$ Reagent (Invitrogen). After being cultured for 24 hours, the cells were digested and collected for the second messenger determination.

In the drug treatment assay, $500 \mu \mathrm{L}$ suspension (about $10^{4}$ cells) of HEK293T cells transfected with pEASY-M ${ }_{1}-\mathrm{CgmAChR}-1$ was added into the 24-well plate with $50 \mu \mathrm{L}$ of $\mathrm{ACh}$ (final concentration of $10^{-7} \mathrm{~mol} \mathrm{~L}^{-1}$ ) (Guo et al., 2013), designating as CgmAChR-1 group. In the CgmAChR-1+PIR group, $50 \mu \mathrm{L}$ of $10.0 \mu \mathrm{mol} \mathrm{L} \mathrm{L}^{-1} \mathrm{PIR}$ was added to incubate the cells. And $3 \mathrm{~h}$ later, $50 \mu \mathrm{L}$ of ACh was then added. Similarly, specific antagonist AFDX, DAMP, PD and DAR for $\mathrm{M}_{2}$ to $\mathrm{M}_{5}$ muscarinic receptors were also added to the wells of transfected HEK293T cells before the addition of ACh. 
155

156

157

The blank group referred to cells without transfection or stimulation, and the control group referred to cells with cell transfection but not stimulated by ACh. After ACh treatment for $1 \mathrm{~h}$, HEK293T cells were digested and harvested. All incubation assays were carried out by 3 replicates.

Fluo-3 AM fluorescent probe (Beyotime, $1.0 \mu \mathrm{mol} \mathrm{L} \mathrm{L}^{-1}$ ) was employed in the examination of intracellular $\mathrm{Ca}^{2+}$, and the cAMP Direct Immunoassay Kit (ab65355, Abcam, Cambridge, UK) was used to measure cAMP concentration as illustrated (Liu et al., 2016). Three duplicates were examined for each test.

\section{5. qRT-PCR analysis of CgmAChR-1 mRNA expression}

Gene relative expression of CgmAChR-1 has been analyzed using qRT-PCR. Samples from 5 different individuals were regarded as one duplicate and three technical duplicates were made for each assay. The fragment (168 bp) of oyster elongation factor (CgEF, CGI_10012474) was detected as endogenous control, and the expression level was normalized using the $2^{-\Delta \Delta \mathrm{Ct}}$ method.

2.6. Determination of the phagocytosis rate and apoptosis index of oyster haemocytes The apoptosis index was examined using Annexin V-FITC Apoptosis Detection Kit (KeyGEN). Before incubating with Annexin V-FITC, haemocytes were mixed with $195 \mu \mathrm{L}$ of Binding Buffer. Then, resuspend haemocytes with $190 \mu \mathrm{L}$ of Binding Buffer after centrifugation at $1000 \mathrm{~g}$ for $5 \mathrm{~min}$. After incubated with Propidium Iodide (PI), the haemocytes resuspension were transferred into a polystyrene round-bottom 
tube and the apoptosis index was detected by flow cytometer (BD, Aria II). The apoptosis index was calculated as Equation (1):

$$
\mathrm{AI}=\frac{\text { Number of apoptoticcells }}{\text { Number of haemocytes }}
$$

In the phagocytosis rate assay, haemocytes were adjusted to $1.0 \times 10^{6}$ cell $\mathrm{mL}^{-1}$ with sterile seawater, and $5 \mu \mathrm{L}$ of Vibrio anguillarum dyed by FITC $\left(1.0 \times 10^{9} \mathrm{CFU}\right.$ $\mathrm{mL}^{-1}$ ) was added to $500 \mu \mathrm{L}$ haemocytes resuspension. After incubation at $18^{\circ} \mathrm{C}$ for $1 \mathrm{~h}$, $10 \mu \mathrm{L}$ of Trypan Blue $\left(100 \mathrm{mg} \mathrm{mL}^{-1}\right)$ was added into the mixture, and $400 \mu \mathrm{L}$ haemocyte resuspension was transferred to a polystyrene round-bottom tube for the determination of phagocytosis rate using $\mathrm{BD}$ flow cytometer. The phagocytosis rate was calculated as Equation (2):

$$
\mathrm{PR}=\frac{\text { Number of phagocytic cells with engulfed bacteria }}{\text { Number of phagocytes }}
$$

Three parallel replicates were performed in each phagocytosis and apoptosis assay.

\subsection{Statistical analysis}

All values obtained were listed as means $\pm \mathrm{SD}$ and analyzed by one-way ANOVA and a Student-Newman-Keus (S-N-K) comparison. Letters (a/b/c, etc.) were marked to illustrate the statistical significance $(p<0.05)$

\section{Results}

3.1. The molecular features of CgmAChR-1 and phylogenic relationship The ORF of CgmAChR-1 (1983 bp, No. EKC34110 in GenBank) was obtained 
from the oyster cDNA library and the polypeptide sequence contained 660 amino acids with a predicted molecular mass of $74.08 \mathrm{kDa}$. The theoretical isoelectric point of CgmAChR-1 was 6.45, and a seven transmembrane domain (from Val51 to Ala641) was revealed using SMART program.

The amino acid sequence of CgmAChR-1 shared $40.7 \%$ similarity with that of Drosophila melanogaster mAChR, and $29.8 \%$ similarity with that of Homo sapiens mAChR. Four conserved cysteine residues (Cys119, Cys608, Cys614 and Cys627) were identified by the alignment of CgmAChR-1 with other two mAChRs (Fig. 1).

Amino acids sequences of mAChRs from $H$. sapiens, D. melanogaster, M. musculus, $C$. gigas et al were employed to construct a phylogenic tree by MEGA program (Fig. 2). These mAChRs were positioned separately in five distinct groups corresponding to $\mathrm{M}_{1}$ to $\mathrm{M}_{5}$. The separation between different receptors was in line with their subtypes. According to the phylogenic tree, CgmAChR-1 was closely matched with $\mathrm{M}_{5}$ muscarinic receptors found in invertebrates.

\subsection{Change of $\mathrm{Ca}^{2+}$ and cAMP concentration after ACh incubation}

Concentrations of $\mathrm{Ca}^{2+}$ in the CgmAChR-1 group after stimulation was increased significantly $(p<0.05$ ), which was 1.38 -fold of that in the control group. Dramatic decreases of intracellular $\mathrm{Ca}^{2+}$ concentration were observed in the CgmAChR-1+PIR, CgmAChR-1+DAMP and CgmAChR-1+DAR groups at $1 \mathrm{~h}$ after ACh incubation, while no significant change was observed in the CgmAChR-1+AFDX and CgmAChR-1+PD groups. On the other hand, the concentrations of intracellular 
cAMP were also increased dramatically after cell transfection and ACh treatment $(p<$ 0.05) (Fig. 3B and Fig. 3C)

3.3. The expression of CgmAChR-1 mRNA in different tissues and in response to LPS stimulation

The qRT-PCR was used to explore the tissue distribution of CgmAChR-1 and the change of its mRNA transcripts responsive to LPS stimulation. The mRNA transcripts of CgmAChR-1 were determined in all the tested tissues including haemocytes, mantle, kidney, gill, gonad, hepatopancreas and adductor muscle. CgmAChR-1 was highly expressed in adductor muscle, whose expression level was 7.06-fold compared with that in haemocytes $(p<0.05)$. CgmAChR-1 was also abundant in hepatopancreas and kidney, and their expression levels were 6.73 and 2.29-fold $(p<$ 0.05) compared with that in haemocytes (Fig. 4).

LPS treatment could significantly induce the mRNA expression of CgmAChR-1 in haemocytes (Fig. 5). According to the qRT-PCR assay, one peak (6.05-fold) of CgmAChR-1 expression was observed $(p<0.05)$ at $24 \mathrm{~h}$ post stimulation.

3.4. The change of TNF mRNA expression after the treatments with CgmAChR-1 antagonists and LPS

The mRNA expression levels of three oyster TNF genes including CGI_10005109,CGI_10005110 and CGI_10006440 in haemocytes were determined by qRT-PCR (Fig. 6). After the treatments with CgmAChR-1 antagonists and LPS, the 
expressions of all the three TNF genes were up-regulated significantly from $3 \mathrm{~h}$ to 24 h after stimulation $(p<0.05)$. Higher expression of CGI_10005109 was observed in the antagonists+LPS group at $3 \mathrm{~h}$ and $6 \mathrm{~h}$ after LPS stimulation $(p<0.05)$, while CGI_10005110 mRNA expression started to increase at $6 \mathrm{~h}$ and $12 \mathrm{~h}$ in the antagonists incubation group $(p<0.05)$. However, no obvious change of CGI_10006440 expression was detected between the LPS and antagonists+LPS groups $(p>0.05)$.

3.5. Phagocytosis rate and apoptosis index of oyster haemocyte after CgmAChR-1 antagonists incubation and LPS stimulation

In order to explore the possible immunomodulation mediated by CgmAChR-1, the phagocytosis rate and apoptosis index of oyster haemocyte were determined by flow cytometry after $12 \mathrm{~h}$ of CgmAChR-1 antagonist incubation and LPS stimulation (Fig. 7A and Fig. 8A). The phagocytosis rate and apoptosis index both increased significantly after LPS stimulation $(p<0.05)$. After an incubation with CgmAChR-1 specific antagonists, the apoptosis index of haemocyte increased dramatically from $13.1 \%$ (the LPS group) to $16.5 \%$ (the antagonists+LPS group) $(p<0.05)$ (Fig. 8B). However, the phagocytosis rate showed no significant change in LPS and antagonists+LPS groups (Fig. 7B).

\section{Discussion}

The molecular features and biological functions of the important components 
cholinergic nervous system, such as ChAT, AChRs, ChT, ACh, AChE and VAChT, have been well investigated in vertebrates (Shi et al., 2015), while some of them (such as ACh, AChE and ChAT) have also been identified in nematodes (Sattelle, 2009), molluscs (Burbring et al., 1953; Shi et al., 2012) and anthropods (Sattelle, 2009). For example, the activation of nAChRs could inhibit the innate immune regulation in insects (Czura et al., 2003; Razani-Boroujerdi et al., 2004; Sopori, 2002). So far, the information about the immune regulation of cholinergic nervous system, especially the function that mAChRs mediates in immunomodulation is still very limited in invertebrates (Razani-Boroujerdi et al., 2008).

Here in this research, we amplified the ORF of a mAChR (CgmAChR-1) from $C$. gigas. The full length of CgmAChR-1 was 1983 bp, and it encoded a protein of 660 amino acids. CgmAChR-1 displayed high similarity of $40.7 \%$ with that of Drosophila melanogaster mAChR. Multiple alignment results suggested that there were four conserved cysteine residues (Cys119, Cys608, Cys614 and Cys627) in CgmAChR-1 with other two mAChRs (Fig. 1). Moreover, according to the phylogenic tree, CgmAChR-1 was closely matched with $\mathrm{M}_{5}$ muscarinic receptors found in invertebrates. The molecular features of CgmAChR-1 suggested that it might belong to the GPCRs family with a similar structure as $\mathrm{M}_{5}$ muscarinic receptor, and it might be critical for calcium signaling, c-fos gene expression, and the immune function of immune cells.

Binding of neurotransmitters to their receptors will trigger the concentration change of various second messengers, relaying signals into downstream pathways 
(Fabbri and Capuzzo, 2010). The intracellular fluxes of $\mathrm{Ca}^{2+}$ and cAMP were determined in this research to explore the binding activity of CgmAChR-1. Besides, antagonists of $\mathrm{M}_{1}$ to $\mathrm{M}_{5}$ muscarinic receptors, including PIR, AFDX, DAMP, PD and DAR, were used in the blocking experiment to ascertain the subtype of CgmAChR-1. The concentration of intracellular $\mathrm{Ca}^{2+}$ increased dramatically $(p<0.05)$ after CgmAChR-1 transfection and ACh treatment. Similarly, cAMP level was also significantly up-regulated. The significant increase of intracellular $\mathrm{Ca}^{2+}$ and cAMP concentration suggested that CgmAChR-1 should belong to the mAChRs. Moreover, incubation of DAMP and DAR caused a dramatic decrease of intracellular $\mathrm{Ca}^{2+}$ concentration, while the concentrations of $\mathrm{Ca}^{2+}$ in the CgmAChR-1+PIR, CgmAChR-1+AFDX and CgmAChR-1+PD groups did not change significantly ( $p>$ 0.05). Such result further indicated that CgmAChR-1 might be $M_{3}$ or $M_{5}$ subtype of mAChRs. It has been announced that the intracellular $\mathrm{Ca}^{2+}$ fluxes would enhance once $\mathrm{M}_{1}, \mathrm{M}_{3}$ and $\mathrm{M}_{5}$ muscarinic receptors were activated (Berridge, 1993; Elaev et al., 1984; Felder, 1995; Hulme et al., 1990). cAMP accumulation also occurred in neuroblastoma cells when the $\mathrm{M}_{3} \mathrm{mAChR}$ pathway was triggered (Baumgold and Fishman, 1988). The phylogeny analysis indicated that CgmAChR-1 might be one of the $\mathrm{M}_{5}$ muscarinic receptors, and the present biological validation using antagonists further implied that CgmAChR-1 might be $\mathrm{M}_{3}$ or $\mathrm{M}_{5}$ subtypes. Collectively, CgmAChR-1 was regarded as a mAChR in oyster, whose function was mediated by intracellular $\mathrm{Ca}^{2+}$ and cAMP. qRT-PCR was employed in the tissue distribution assay of CgmAChR-1 for a 
better exploration of its physiological role in oyster. In the present study, the mRNA transcripts of CgmAChR-1 were expressed in every detected oyster tissue, suggesting that CgmAChR-1 was the key hub-gene in marine molluscs. Besides, since hepatopancreas is thought to be an important immune tissue in molluscs (Sun et al., 2014b; Wootton et al., 2003), the high CgAChR-1 expression in hepatopancreas indicated that CgmAChR-1 should be critical for the immune regulation in oyster.

The circling haemocytes mediates a complex process in which immune and neuroendocrine responses are intermixed to help the lower forms of life successfully live and survive from environments full of potentially agents and substances (Costa et al., 2009; Travers et al., 2008). Haemocytes mediate the immune regulation by neurotransmitters mainly with the involvement of receptors expressed on the cell surface. The mRNA expression level of CgmAChR-1 significantly increased $(p<0.05)$ at $24 \mathrm{~h}$ post immune stimulation. Our previous study proved that the release of ACh could be positively induced under LPS stimulation in scallop (Shi et al., 2014). Thus, the increase of both $\mathrm{ACh}$ and its receptor might indicate that during the immune regulation, CgmAChR-1 play important role in the cholinergic neuroendocrine system. Besides, when the pathogens are recognized by haemocytes, cytokines are produced to enhance the immunomodulation (Guo et al., 2013). In this research, the recognition of LPS by pathogen recognition receptors was found to enhance the synthesis of cytokines (e.g., TNF- $\alpha$ ) and transcription factors (e.g., NF- $\kappa$ B), and then induce a higher expression of $\mathrm{CgmAChR}-1$, which might up-regulate the immune regulation to accelerate the elimination of pathogens. However, the sustained high-level immune 
response would in turn cause immune injury. In order to avoid killing normal cells and maintain homeostasis, more receptors with inhibitory effect such as $\alpha$-adrenergic receptor (Zhou et al., 2013) will be expressed on the haemocyte surface to make the immunomodulation come down when the pathogens are totally eliminated (Sternberg, 2006). The fall of CgmAChR-1 mRNA expression level at $48 \mathrm{~h}$ should be the indication of immune response switching from higher to the normal level. The above results implied that $\mathrm{CgmAChR}-1$ was critical for the immune regulation in oyster and its expression could be regulated to balance the cholinergic modulation during the immune activities.

Appropriate innate immune response and inflammation control depend on the interaction between nervous and immune systems (Pavlov and Tracey, 2005; Tracey, 2002). As the key molecule in cholinergic nervous system, ACh inhibited the production of TNF, (IL)-1 $\beta$, IL-6 and IL-18 in invertebrates [7]. Previous experimental evidences have indicated that alpha7 nicotinic acetylcholine receptors are required for cholinergic anti-inflammatory signaling (Gallowitsch-Puerta and Pavlov, 2007), but the involvement of mAChRs in such process remains unclear in marine invertebrates. In this paper, the expression of three oyster TNFs (CGI_10005109, CGI_10005110 and CGI_10006440) as well as haemocyte phagocytosis rate and apoptosis index were determined to further understand the immunomodulation mediated by CgmAChR-1. The expression of CGI_10005109 and CGI_10005110 was up-regulated after LPS treatment, and the up-regulation was further enhanced by mAChR antagonist. LPS stimulation could activate the 
neuroendocrine system to release neurotransmitters including enkephalin (ENK) (Liu et al., 2015a; Liu et al., 2015b), norepinephrine (NE) (Zhou et al., 2011) and ACh (Shi et al., 2014) to regulate the immune responses through cytokines, such as IL-17 (Xin et al., 2015), IFN- $\gamma$ (Zhang et al., 2015) and TNF- a (Sun et al., 2014a) in mollusc. The change of TNF expression might due to the effects of neurotransmitter regulation. The up-regulation of TNF after the treatment with antagonist suggested that ACh could inhibit the expression of TNF by binding with CgmAChR-1, which was in coherent with that in mammals. Moreover, phagocytosis rate and apoptosis index both increased significantly after LPS stimulation $(p<0.05)$, and CgmAChR-1 specific antagonists could induce significant increase of apoptosis index, indicating that the blockage of mAChR in oyster could promote TNF expression, and then improve haemocyte apoptosis to regulate cellular response against infection.

In conclusion, an ACh specific receptor CgmAChR-1 was identified from oyster C. gigas, which was distributed mainly in gill, adductor muscle and hepatopancreas. LPS could enhance the expression of CgmAChR-1 in haemocytes, while the blockage of CgmAChR-1 using receptor antagonists before LPS stimulation promoted the expression of oyster TNF, resulting in the increase of haemocyte apoptosis index. These results suggested that mAChRs in oyster also played important roles as nAChRs in cholinergic neuroendocrine-immune regulation to protect the host from pathogen infection and maintain homeostasis. 


\section{Acknowledgements}

We wish to be thankful for the tremendous support from all the laboratory members. This research was supported by grants from National Science Foundation of China (Nos. 41276169, 41206151) and Chinese National '863' Program (No. 2014AA093501) from the Chinese Ministry of Science and Technology, earmarked fund (CARS-48) from Modern Agro-industry Technology Research System.

\section{Figure legend}

Fig.1. Multiple alignment of CgmAChR-1 compared with other mAChRs from model species based on their deduced amino acid sequences.

Fig.2. Neighbor-joining (NJ) phylogeny tree of mAChRs from various creatures, such as $H$. sapiens, D. melanogaster, and C. gigas.

Fig.3. Change of $\mathrm{Ca}^{2+}$ and cAMP after muscarinic receptor antagonist incubation and ACh treatment. (A) $\mathrm{Ca}^{2+}$ concentration determined by flow cytometry. (B) Concentration change of $\mathrm{Ca}^{2+}$ after cell transfection, $\mathrm{M}_{1}$ to $\mathrm{M}_{5}$ muscarinic receptor antagonist incubation and acetylcholine stimulation. (C) Concentration change of cAMP after cell transfection, $\mathrm{M}_{1}$ to $\mathrm{M}_{5}$ muscarinic receptor antagonist incubation and acetylcholine stimulation. 
397 Fig.4. Tissue distribution of CgmAChR-1 determined by qRT-PCR.

Fig.5. Expression of CgmAChR-1 in oyster haemocytes under LPS stimulation.

400

401

Fig.6. Relative expression of oyster TNF genes (CGI_10005109 (A); CGI_10005110

402

(B) and CGI_10006440(C)) in haemocytes after mAChRs antagonists incubation and

403

LPS stimulation.

404

405

406

Fig.7. Effects of in vivo incubation with CgmAChR-1 antagonist and stimulation of . LPS on haemocyte phagocytosis rate. (A) Determination of haemocyte phagocytosis

407

408

409

410

411

412

413

414

415

416 rate by flow cytometry. (B) The overall change of haemocyte phagocytosis rate after the incubation of CgmAChR-1 antagonist and LPS stimulation.

Fig.8. Effects of in vivo incubation with CgmAChR-1 antagonist and stimulation of LPS on haemocyte apoptosis index. (A) Determination of haemocyte apoptosis index by flow cytometry. (B) The overall change of haemocyte apoptosis index after the incubation of CgmAChR-1 antagonist and LPS stimulation. 


\section{Reference}

Aizono, Y., Endo, Y., Sattelle, D.B., Shirai, Y., 1997. Prothoracicotropic hormone-producing neurosecretory cells in the silkworm, Bombyx mori, express a muscarinic acetylcholine receptor. Brain Res 763, 131-136.

Baumgold, J., Fishman, P.H., 1988. Muscarinic Receptor-Mediated Increase in Camp Levels in Sk-N-Sh Human Neuro-Blastoma Cells. Biochem Bioph Res Co 154, 1137-1143.

Berridge, M.J., 1993. Inositol Trisphosphate and Calcium Signaling. Nature 361, 315-325.

Blake, A.D., Anthony, N.M., Chen, H.H., Harrison, J.B., Nathanson, N.M., Sattelle, D.B., 1993. Drosophila nervous system muscarinic acetylcholine receptor: transient functional expression and localization by immunocytochemistry. Mol Pharmacol 44, 716-724.

Borovikova, L.V., Ivanova, S., Zhang, M.H., Yang, H., Botchkina, G.I., Watkins, L.R., Wang, H.C., Abumrad, N., Eaton, J.W., Tracey, K.J., 2000. Vagus nerve stimulation attenuates the systemic inflammatory response to endotoxin. Nature 405, 458-462.

Burbring, E., Burn, J.H., Shelley, H.J., 1953. Acetylcholine and ciliary movement in the gill plates of Mytilus edulis. Proc R Soc Lond B Biol Sci 141, 445-466.

Caulfield, M.P., Birdsall, N.J., 1998. International Union of Pharmacology. XVII. Classification of muscarinic acetylcholine receptors. Pharmacol Rev 50, 279-290.

Costa, M.M., Prado-Alvarez, M., Gestal, C., Li, H., Roch, P., Novoa, B., Figueras, A., 2009. Functional and molecular immune response of Mediterranean mussel (Mytilus galloprovincialis) haemocytes against pathogen-associated molecular patterns and bacteria. Fish Shellfish Immun 26, 515-523.

Czura, C.J., Friedman, S.G., Tracey, K.J., 2003. Neural inhibition of inflammation: the cholinergic anti-inflammatory pathway. J Endotoxin Res 9, 409-413.

Dale, H.H., 1914. The action of certain esters and ethers of choline, and their relation to muscarine. Journal of Pharmacology and Experimental Therapeutics 6, 147-190.

Deiana, S., Platt, B., Riedel, G., 2011. The cholinergic system and spatial learning. Behav Brain Res 221, 389-411.

Elaev, N.R., Panova, M.K., Mikhailova, E.V., Kharitonova, N.V., 1984. [Intracellular hormonal function of acetylcholine and noradrenaline: the regulation of the catalase level in liver cells]. Probl Endokrinol (Mosk) 30, 69-72.

Fabbri, E., Capuzzo, A., 2010. Cyclic AMP signaling in bivalve molluscs: an overview. J Exp Zool A Ecol Genet Physiol 313, 179-200.

Felder, C.C., 1995. Muscarinic Acetylcholine-Receptors - Signal-Transduction through Multiple Effectors. Faseb Journal 9, 619-625.

Fujii, T., Watanabe, Y., Inoue, T., Kawashima, K., 2003. Upregulation of mRNA encoding the M5 muscarinic acetylcholine receptor in human T- and B-lymphocytes during immunological responses. Neurochem Res 28, 423-429.

Gallowitsch-Puerta, M., Pavlov, V.A., 2007. Neuro-immune interactions via the cholinergic anti-inflammatory pathway. Life Sci 80, 2325-2329.

Guo, Y., Wang, L., Zhou, Z., Wang, M., Liu, R., Wang, L., Jiang, Q., Song, L., 2013. An opioid growth factor receptor (OGFR) for [Met5]-enkephalin in Chlamys farreri. Fish Shellfish Immunol 34, 1228-1235.

Harrison, J.B., Chen, H.H., Blake, A.D., Huskisson, N.S., Barker, P., Sattelle, D.B., 1995. Localization in the nervous system of Drosophila melanogaster of a C-terminus anti-peptide antibody to a cloned 
Drosophila muscarinic acetylcholine receptor. J Neuroendocrinol 7, 347-352.

Hulme, E.C., Birdsall, N.J., Buckley, N.J., 1990. Muscarinic receptor subtypes. Annu Rev Pharmacol Toxicol 30, 633-673.

Hurst, R., Rollema, H., Bertrand, D., 2013. Nicotinic acetylcholine receptors: from basic science to therapeutics. Pharmacol Ther 137, 22-54.

Kawashima, K., Fujii, T., Moriwaki, Y., Misawa, H., 2012. Critical roles of acetylcholine and the muscarinic and nicotinic acetylcholine receptors in the regulation of immune function. Life Sci 91, 1027-1032.

Krieg, T., Cui, L., Qin, Q.N., Cohen, M.V., Downey, J.A., 2004. Mitochondrial ROS generation following acetylcholine-induced EGF receptor transactivation requires metalloproteinase cleavage of proHB-EGF. J Mol Cell Cardiol 36, 435-443.

Krieg, T., Philipp, S., Cui, L., Dostmann, W.R., Downey, J.M., Cohen, M.V., 2005. Peptide blockers of PKG inhibit ROS generation by acetylcholine and bradykinin in cardiomyocytes but fail to block protection in the whole heart. Am J Physiol-Heart C 288, H1976-H1981.

Kruse, A.C., Hu, J., Pan, A.C., Arlow, D.H., Rosenbaum, D.M., Rosemond, E., Green, H.F., Liu, T., Chae, P.S., Dror, R.O., Shaw, D.E., Weis, W.I., Wess, J., Kobilka, B.K., 2012. Structure and dynamics of the M3 muscarinic acetylcholine receptor. Nature 482, 552-556.

Liu, Z., Wang, L., Zhou, Z., Sun, Y., Wang, M., Wang, H., Hou, Z., Gao, D., Gao, Q., Song, L., 2016. The simple neuroendocrine-immune regulatory network in oyster Crassostrea gigas mediates complex functions. Sci Rep 6, 26396.

Liu, Z., Zhou, Z., Wang, L., Jiang, S., Wang, W., Zhang, R., Song, L., 2015a. The immunomodulation mediated by a delta-opioid receptor for [Met(5)]-enkephalin in oyster Crassostrea gigas. Dev Comp Immunol 49, 217-224.

Liu, Z., Zhou, Z., Wang, L., Song, X., Chen, H., Wang, W., Liu, R., Wang, M., Wang, H., Song, L., $2015 b$. The enkephalinergic nervous system and its immunomodulation on the developing immune system during the ontogenesis of oyster Crassostrea gigas. Fish Shellfish Immunol 45, 250-259.

Lucas-Meunier, E., Fossier, P., Baux, G., Amar, M., 2003. Cholinergic modulation of the cortical neuronal network. Pflugers Arch 446, 17-29.

MacDonald, K., Kimber, M.J., Day, T.A., Ribeiro, P., 2015. A constitutively active G protein-coupled acetylcholine receptor regulates motility of larval Schistosoma mansoni. Mol Biochem Parasitol 202, 29-37.

Norman, G.J., Morris, J.S., Karelina, K., Weil, Z.M., Zhang, N., Al-Abed, Y., Brothers, H.M., Wenk, G.L., Pavlov, V.A., Tracey, K.J., DeVries, A.C., 2011. Cardiopulmonary Arrest and Resuscitation Disrupts Cholinergic Anti-Inflammatory Processes: A Role for Cholinergic 7 Nicotinic Receptors. Journal of Neuroscience 31, 3446-3452.

Pavlov, V.A., Tracey, K.J., 2005. The cholinergic anti-inflammatory pathway. Brain Behav Immun 19, 493-499.

Razani-Boroujerdi, S., Behl, M., Hahn, F.F., Pena-Philippides, J.C., Hutt, J., Sopori, M.L., 2008. Role of muscarinic receptors in the regulation of immune and inflammatory responses. J Neuroimmunol 194, 83-88.

Razani-Boroujerdi, S., Singh, S.P., Knall, C., Hahn, F.F., Pena-Philippides, J.C., Kalra, R., Langley, R.J., Sopori, M.L., 2004. Chronic nicotine inhibits inflammation and promotes influenza infection. Cell Immunol 230, 1-9.

Rosas-Ballina, M., Tracey, K.J., 2009. Cholinergic control of inflammation. J Intern Med 265, 663-679. 
Sattelle, D.B., 2009. Invertebrate nicotinic acetylcholine receptors-targets for chemicals and drugs important in agriculture, veterinary medicine and human health. Journal of Pesticide Science 34, 233-240.

Shi, X., Wang, L., Zhou, Z., Liu, R., Li, Y., Song, L., 2014. Acetylcholine modulates the immune response in Zhikong scallop Chlamys farreri. Fish Shellfish Immunol 38, 204-210.

Shi, X., Zhou, Z., Wang, L., Wang, M., Shi, S., Wang, Z., Song, L., 2015. The immunomodulation of nicotinic acetylcholine receptor subunits in Zhikong scallop Chlamys farreri. Fish Shellfish Immunol 47, 611-622.

Shi, X., Zhou, Z., Wang, L., Yue, F., Wang, M., Yang, C., Song, L., 2012. The immunomodulation of acetylcholinesterase in zhikong scallop Chlamys farreri. PLoS One 7, e30828.

Sopori, M., 2002. Effects of cigarette smoke on the immune system. Nat Rev Immunol 2, 372-377. Sternberg, E.M., 2006. Neural regulation of innate immunity: a coordinated nonspecific host response to pathogens. Nat Rev Immunol 6, 318-328.

Sun, Y., Zhou, Z., Wang, L., Yang, C., Jianga, S., Song, L., 2014a. The immunomodulation of a novel tumor necrosis factor (CgTNF-1) in oyster Crassostrea gigas. Dev Comp Immunol 45, 291-299.

Sun, Z., Yang, C., Wang, L., Wang, X., Wang, J., Yue, F., Liu, R., Zhang, H., Song, L., 2014b. The protein expression profile in hepatopancreas of scallop Chlamys farreri under heat stress and Vibrio anguillarum challenge. Fish Shellfish Immunol 36, 252-260.

Tracey, K.J., 2002. The inflammatory reflex. Nature 420, 853-859.

Travers, M.A., Mirella da Silva, P., Le Goic, N., Marie, D., Donval, A., Huchette, S., Koken, M., Paillard, C., 2008. Morphologic, cytometric and functional characterisation of abalone (Haliotis tuberculata) haemocytes. Fish Shellfish Immunol 24, 400-411.

Trimmer, B.A., 1995. Current excitement from insect muscarinic receptors. Trends Neurosci 18, 104-111.

Van der Zee, E.A., Buwalda, B., Strubbe, J.H., Strosberg, A.D., Luiten, P.G.M., 1992. Immunocytochemical localization of muscarinic acetylcholine receptors in the rat endocrine pancreas. Cell and Tissue Research 269, 99-106.

Van der Zee, E.A., Platt, B., Riedel, G., 2011. Acetylcholine: future research and perspectives. Behav Brain Res 221, 583-586.

Wang, H.C., Bloom, O., Zhang, M.H., Vishnubhakat, J.M., Ombrellino, M., Che, J.T., Frazier, A., Yang, H., Ivanova, S., Borovikova, L., Manogue, K.R., Faist, E., Abraham, E., Andersson, J., Andersson, U., Molina, P.E., Abumrad, N.N., Sama, A., Tracey, K.J., 1999. HMG-1 as a late mediator of endotoxin lethality in mice. Science 285, 248-251.

Wess, J., 1996. Molecular biology of muscarinic acetylcholine receptors. Crit Rev Neurobiol 10, 69-99. Wootton, E.C., Dyrynda, E.A., Ratcliffe, N.A., 2003. Bivalve immunity: comparisons between the marine mussel (Mytilus edulis), the edible cockle (Cerastoderma edule) and the razor-shell (Ensis siliqua). Fish Shellfish Immun 15, 195-210.

Xin, L., Zhang, H., Zhang, R., Li, H., Wang, W., Wang, L., Wang, H., Qiu, L., Song, L., 2015. CgIL17-5, an ancient inflammatory cytokine in Crassostrea gigas exhibiting the heterogeneity functions compared with vertebrate interleukin17 molecules. Dev Comp Immunol 53, 339-348.

Zhang, R., Liu, R., Wang, W., Xin, L., Wang, L., Li, C., Song, L., 2015. Identification and functional analysis of a novel IFN-like protein (CgIFNLP) in Crassostrea gigas. Fish Shellfish Immunol 44, 547-554. Zhou, Z., Jiang, Q., Wang, M., Yue, F., Wang, L., Wang, L., Li, F., Liu, R., Song, L., 2013. Modulation of haemocyte phagocytic and antibacterial activity by alpha-adrenergic receptor in scallop Chlamys 
farreri. Fish Shellfish Immunol 35, 825-832.

550 Zhou, Z., Wang, L., Shi, X., Zhang, H., Gao, Y., Wang, M., Kong, P., Qiu, L., Song, L., 2011. The 551 modulation of catecholamines to the immune response against bacteria Vibrio anguillarum challenge 552 in scallop Chlamys farreri. Fish Shellfish Immunol 31, 1065-1071.

553 Zimring, J.C., Kapp, L.M., Yamada, M., Wess, J., Kapp, J.A., 2005. Regulation of CD8+ cytolytic T 554 lymphocyte differentiation by a cholinergic pathway. J Neuroimmunol 164, 66-75.

555

556

557 
Crassostrea gigas Homo sapiens - -

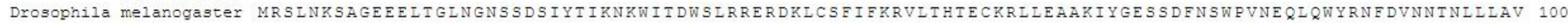

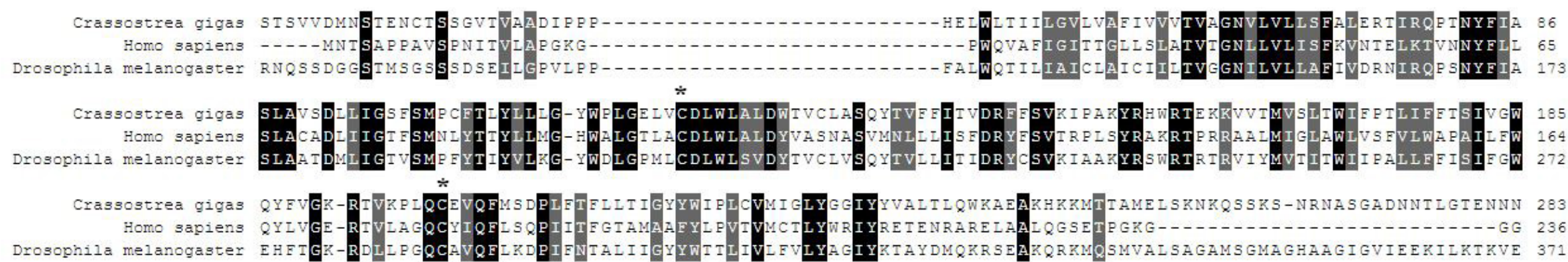

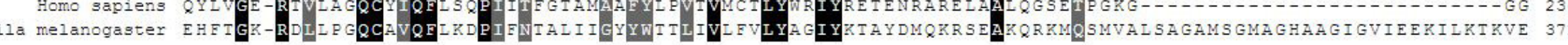

Crassostrea gigas GRSMRPDESTSFTKAP-1-1Homo sapiens SSSS----SERSQP---1 Drosophila melanogaster LAGDQTDIDSACTIVI-- -

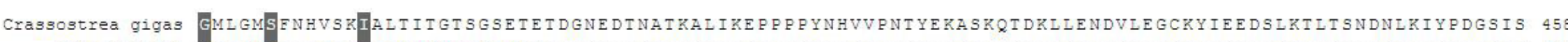

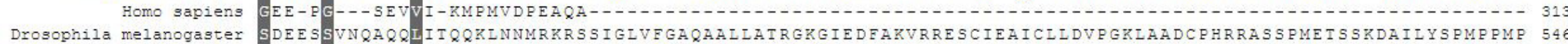

Crassostrea gigas FDATIDESCSPVWKRREGRYLPIPIAED-- - - - SSNTISTTLEGDSSIRHASNDDEMSKRIPSNGTSAVHSRDRNEDEDVDSDANRERPSIMAPLQNLV 552

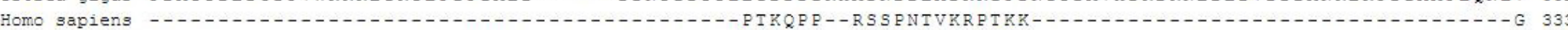
Drosophila melanogaster LSPKVRTSTPQTGIPQSAAGVTPPVPLERIERETSDSNTNKMPSTSGTTSSTGGVGGGGEQDGVGTKKNAGDDDANRERSLAASRNSSKRAFIHSIG 64

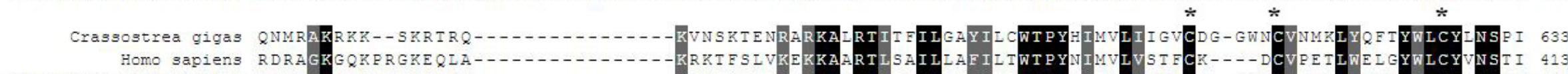

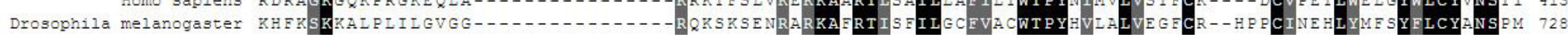

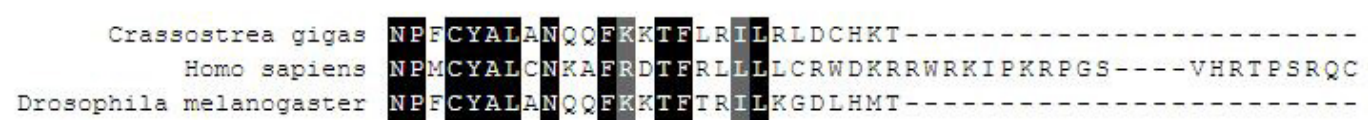

Figure 1 


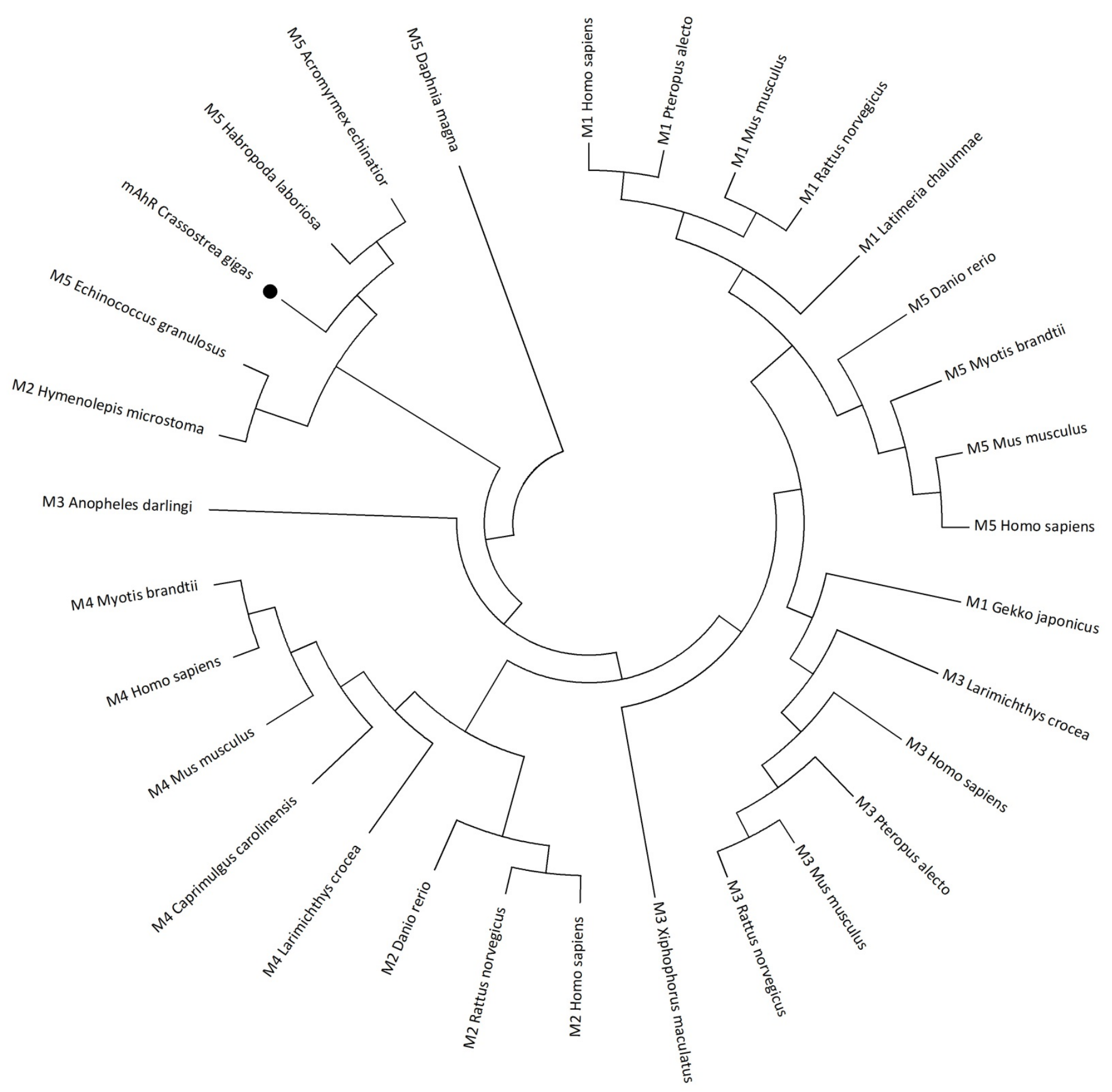

Figure 2 
A
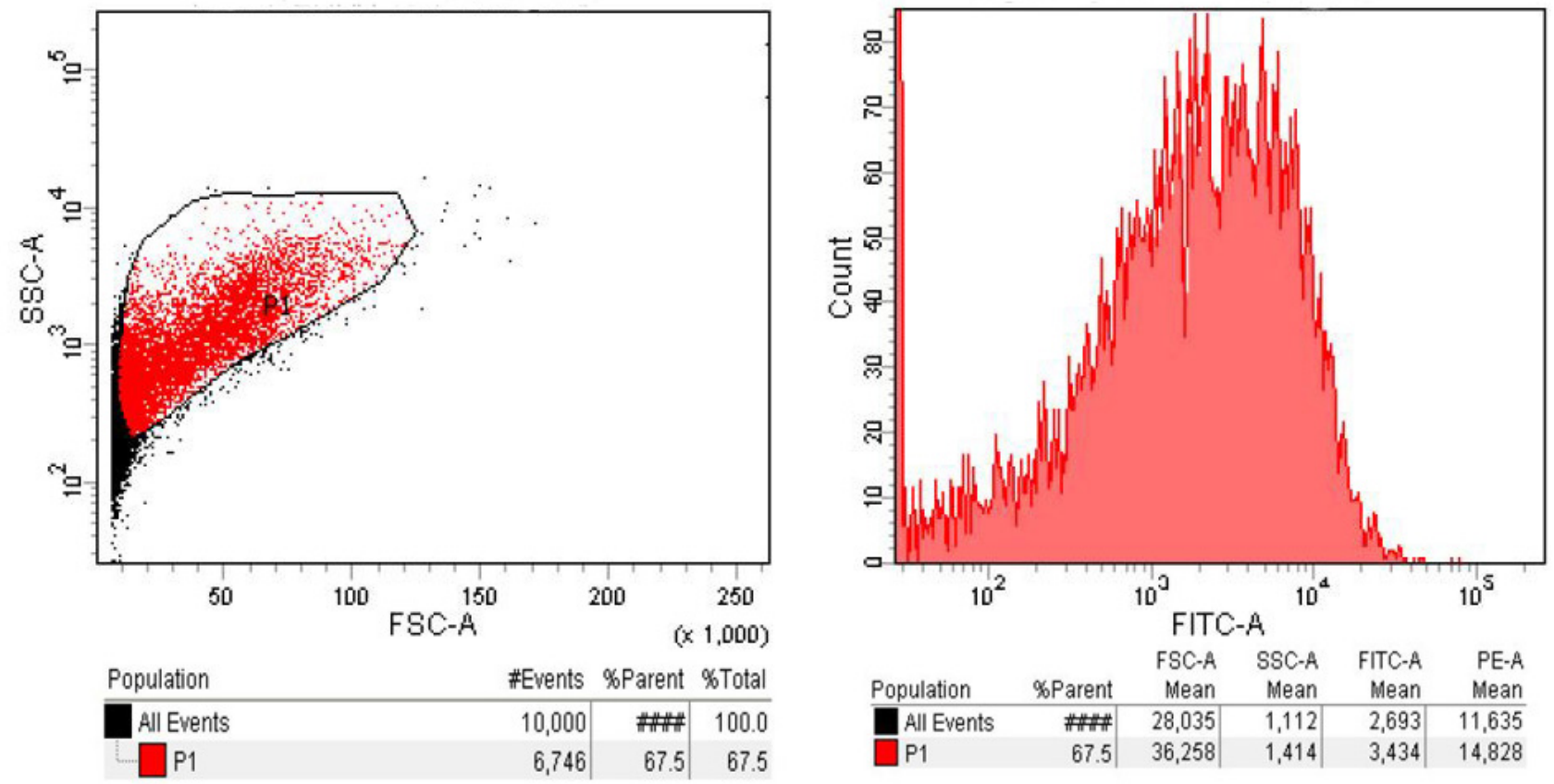

B

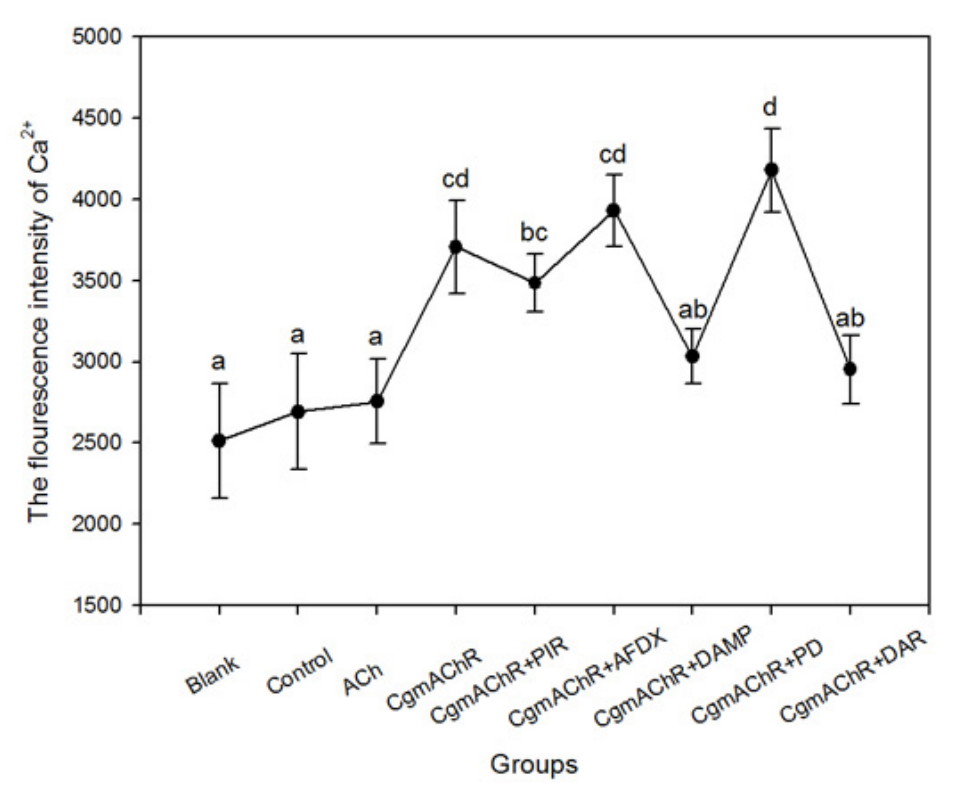

C

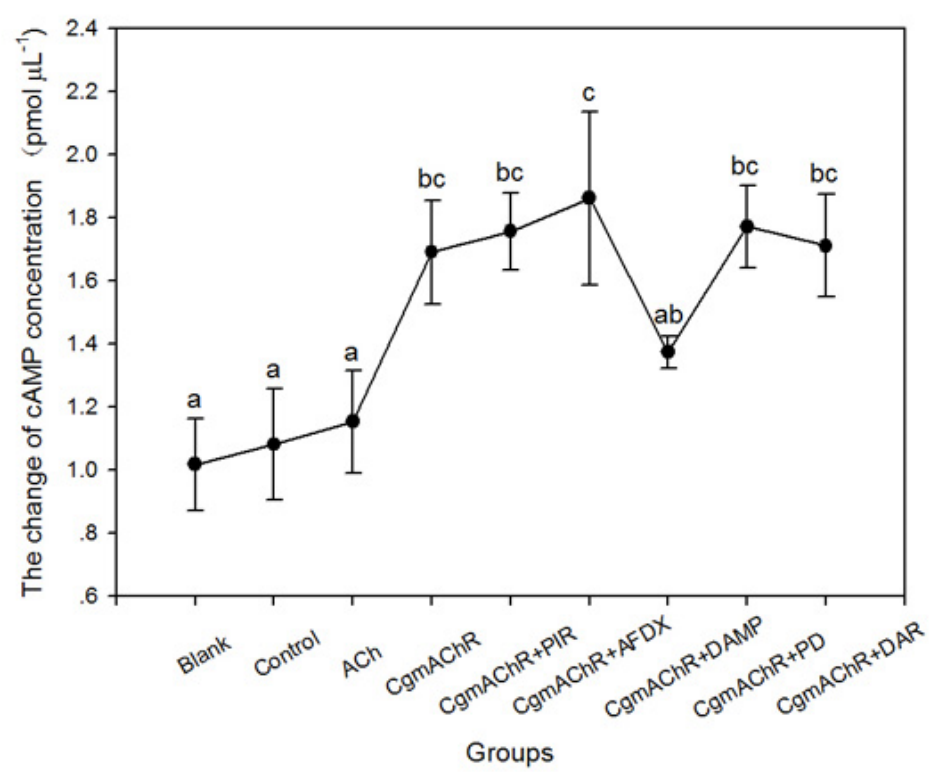

Figure 3 


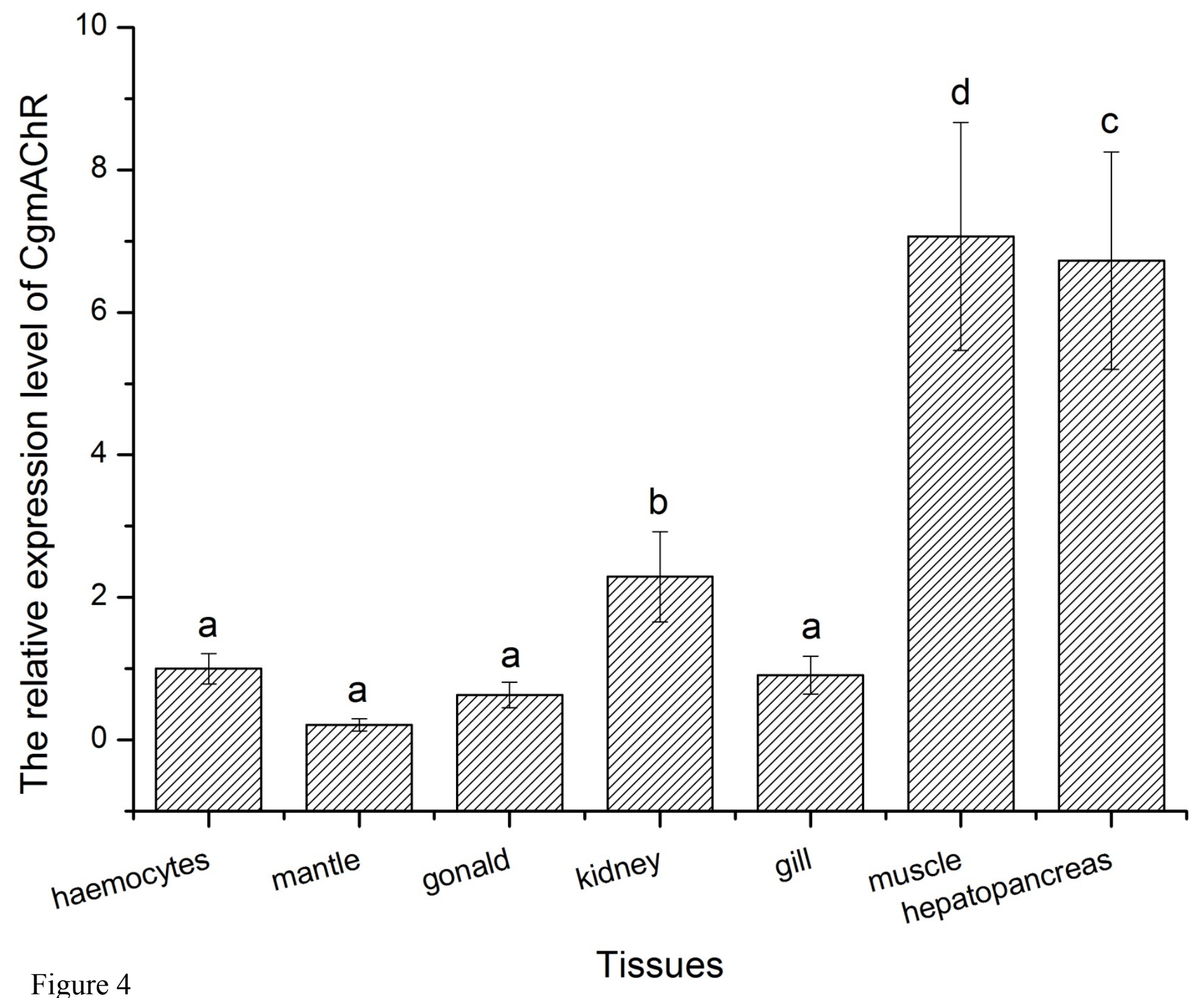




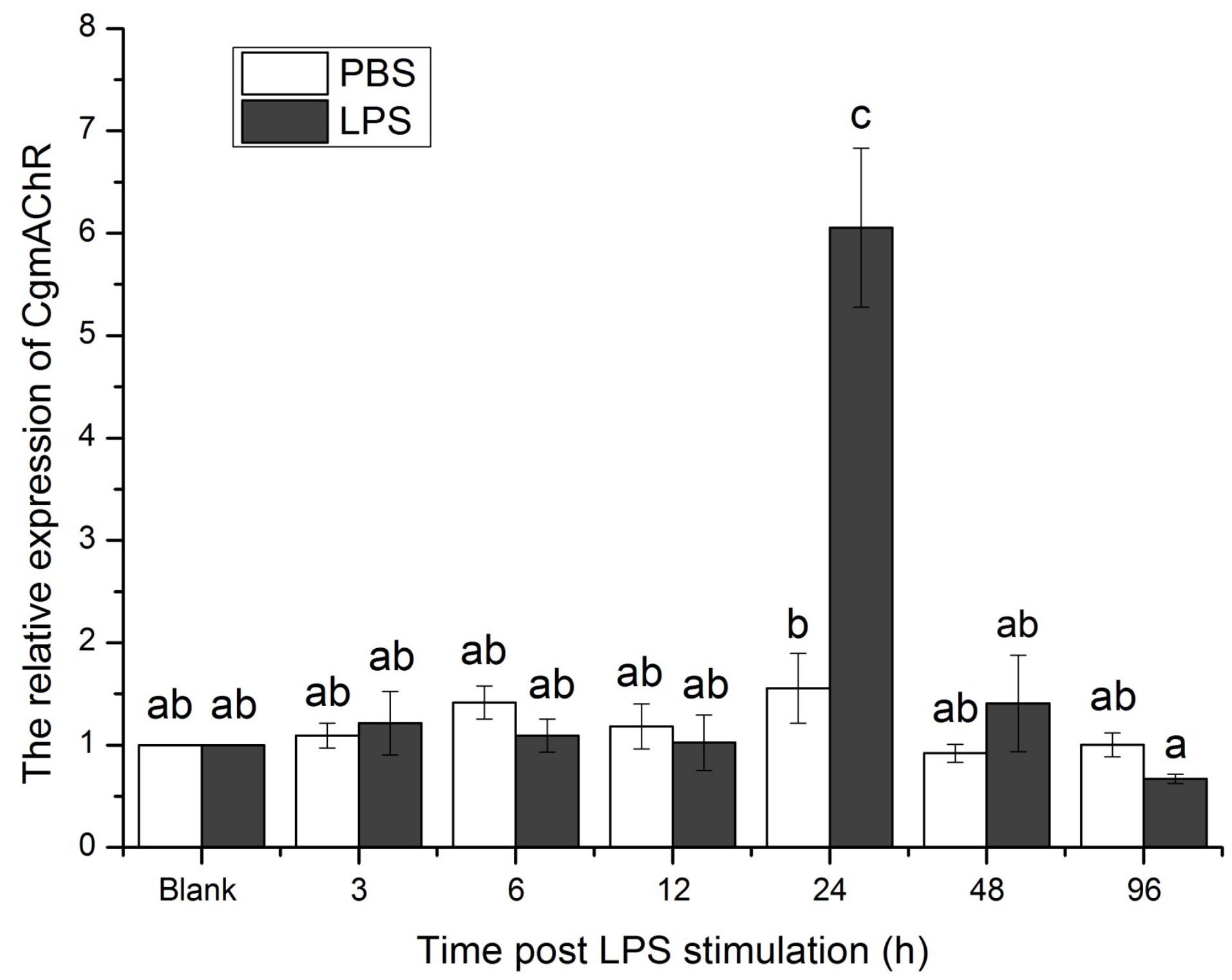

Figure 5 

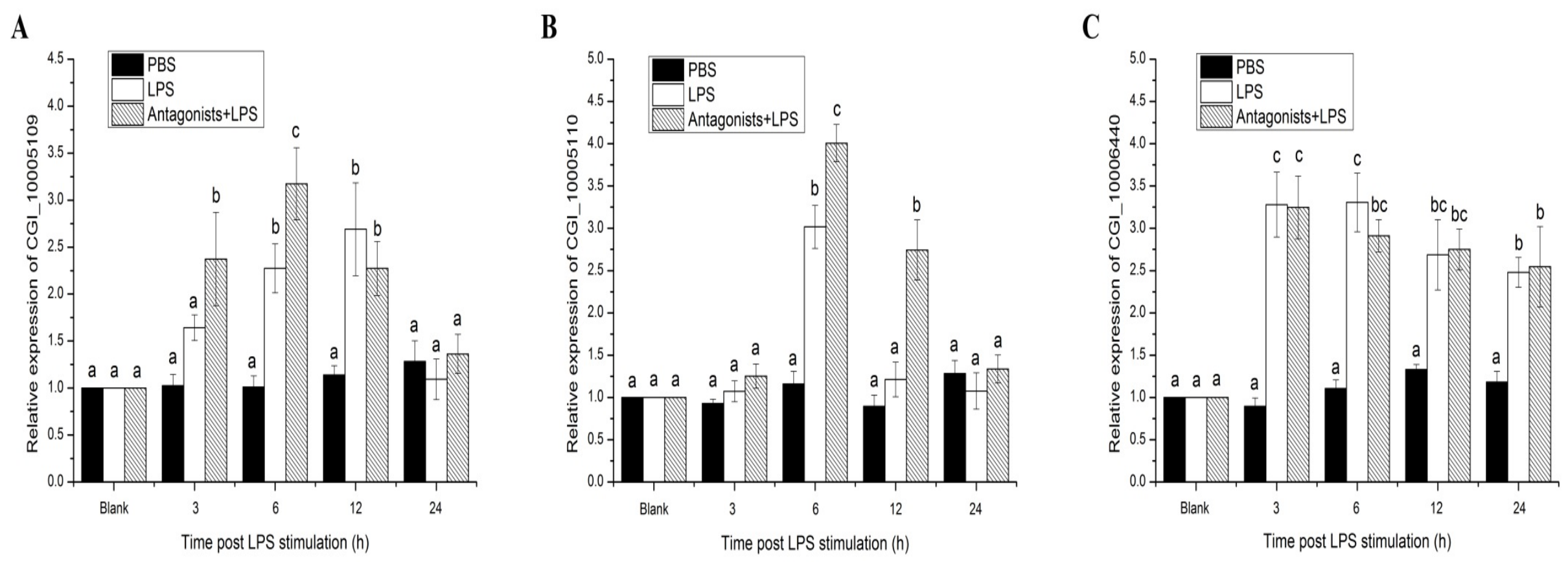

Figure 6 
A

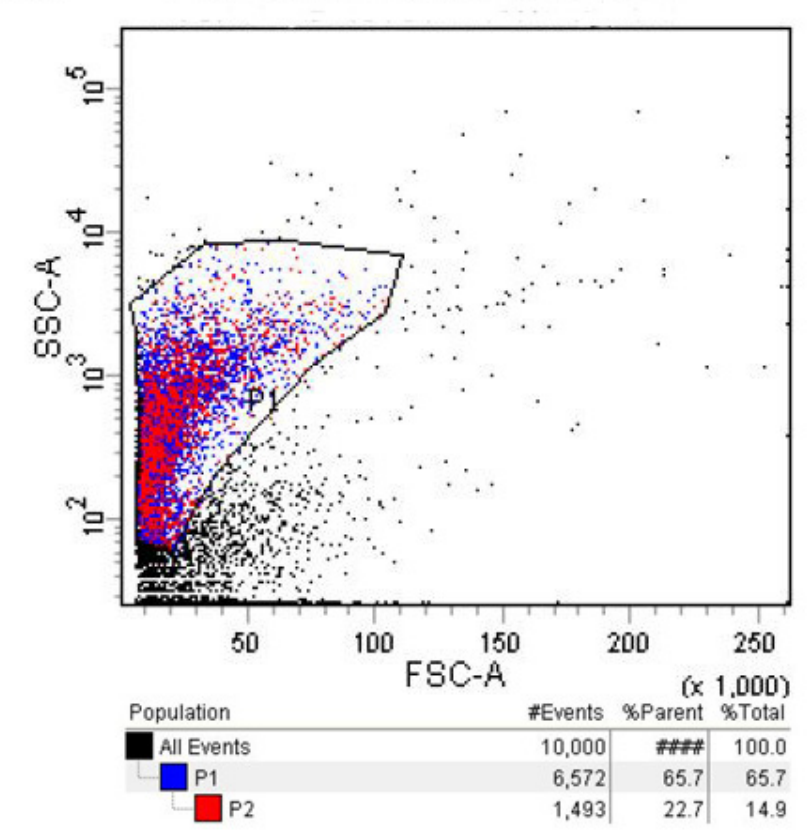

B

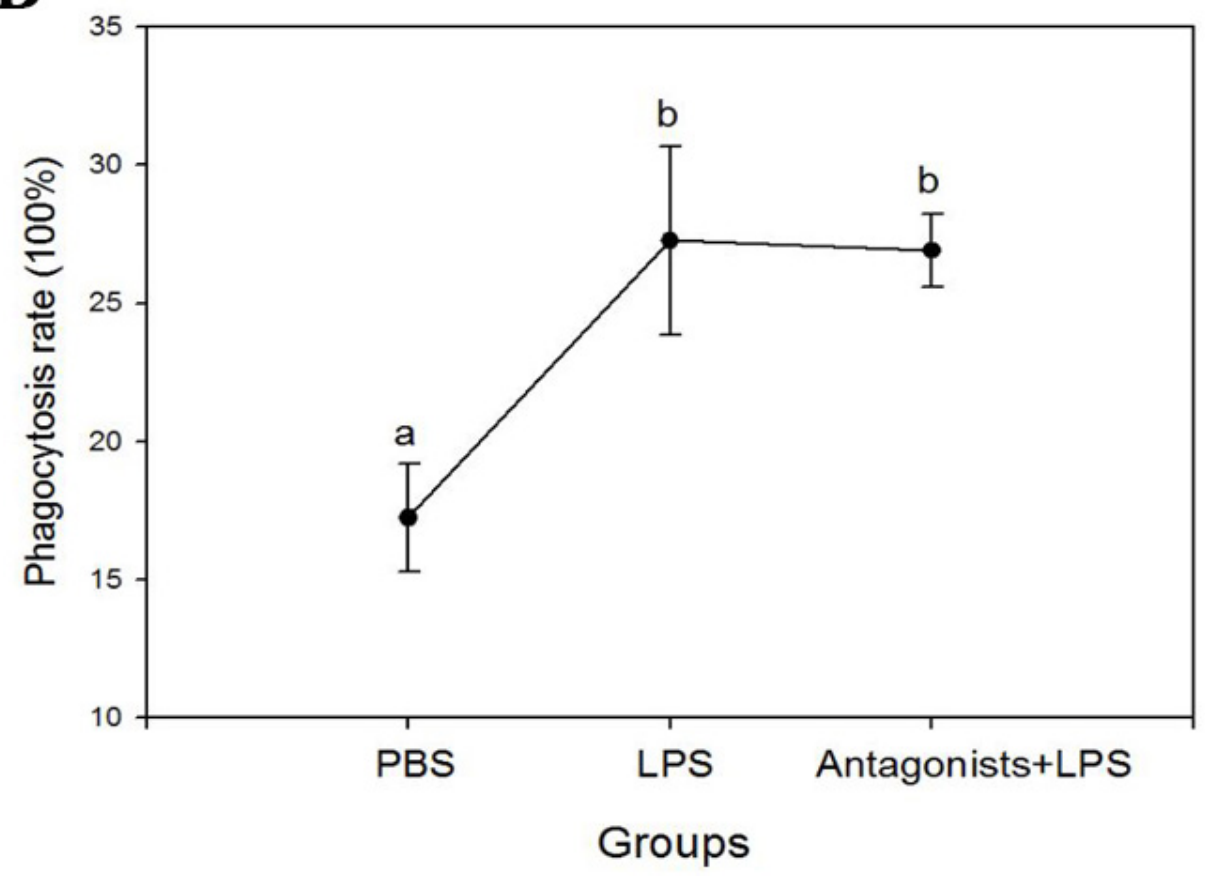

Figure 7

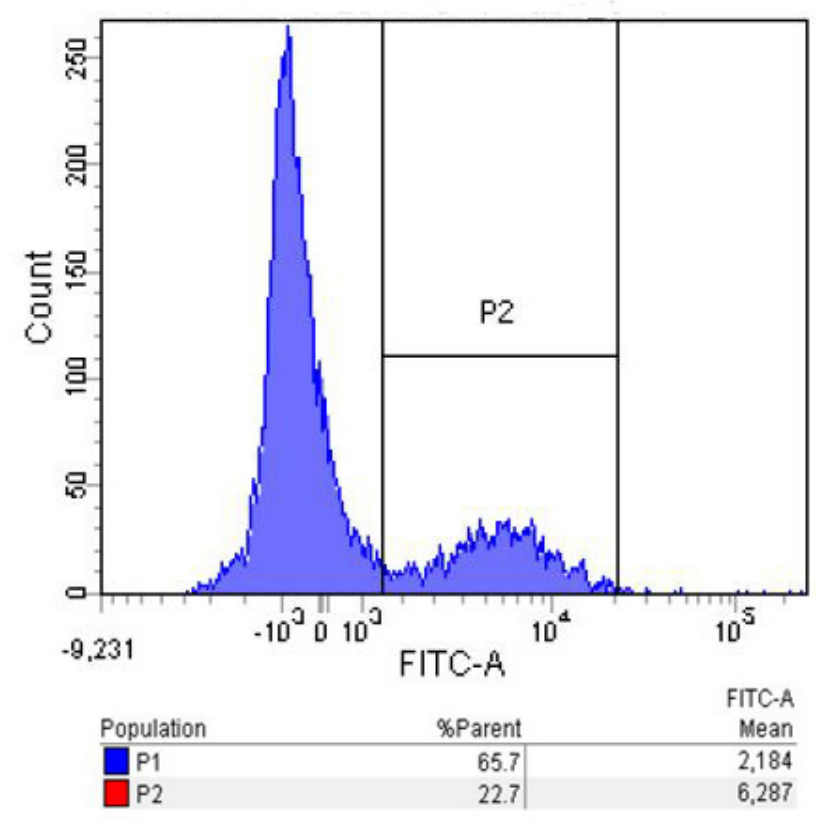


A
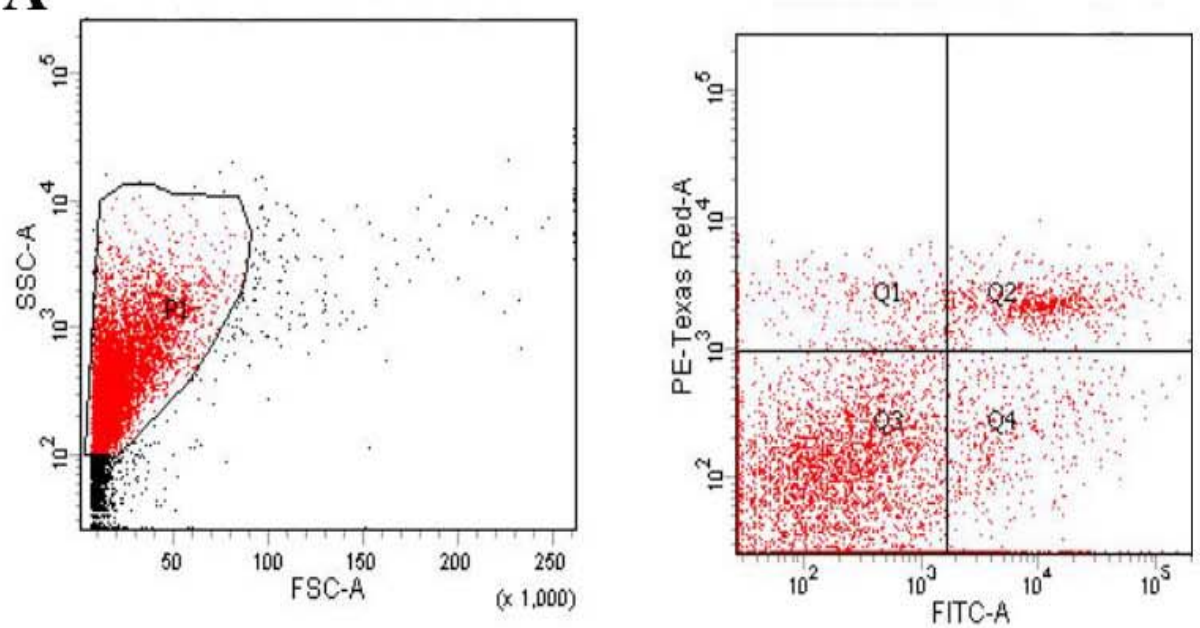

\begin{tabular}{|c|c|c|c|}
\hline Population & \%Parent & $\begin{array}{l}\text { FITC-A } \\
\text { Mean }\end{array}$ & $\begin{array}{r}\text { PE-Texas Red-A } \\
\text { Mean }\end{array}$ \\
\hline$\square \mathrm{P} 1$ & 81.8 & 1,868 & 351 \\
\hline 凶Q1 & 3.7 & 605 & 2,633 \\
\hline $\bar{\nabla} \mathrm{Q}_{2}$ & 7.2 & 13,345 & 2,391 \\
\hline $\bar{\nabla} \mathrm{Q3}$ & 81.8 & 181 & 82 \\
\hline$\vec{\nabla}_{Q 4}$ & 7.3 & 10,126 & 204 \\
\hline
\end{tabular}

Figure 8
B

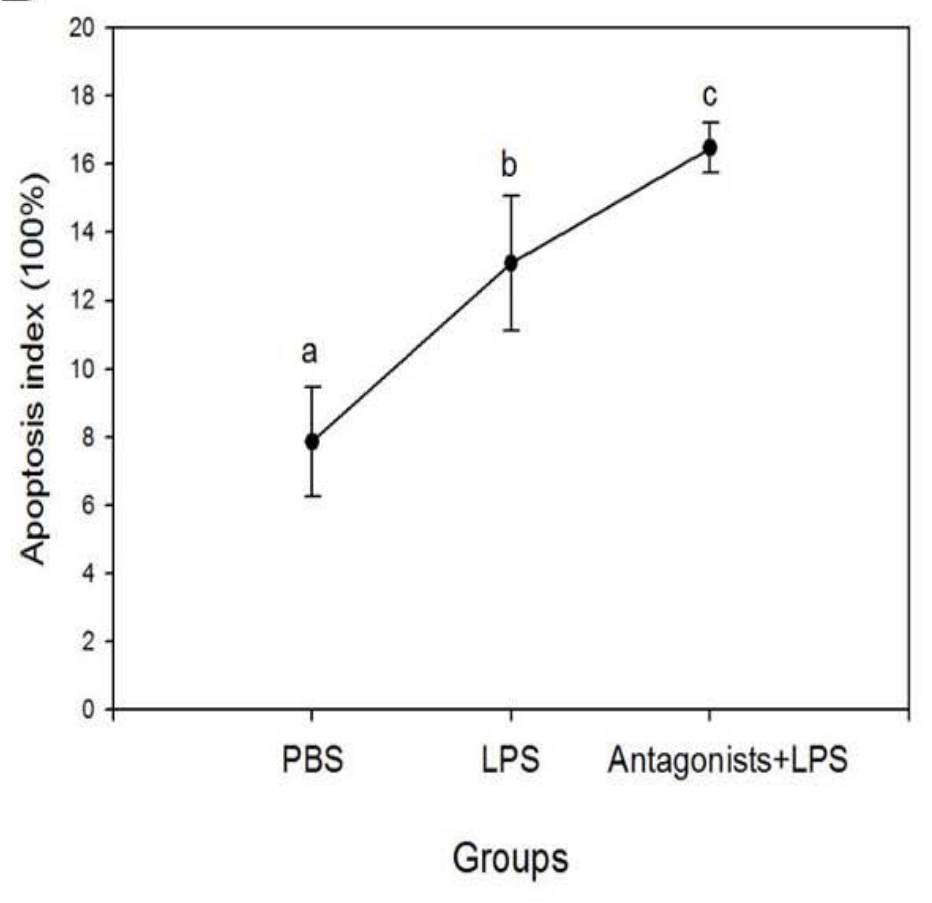




\section{Table 1}

Sequences of the primers used in the experiment.

\begin{tabular}{|c|c|c|}
\hline Primer & Sequence $\left(5^{\prime}-3^{\prime}\right)$ & Sequence information \\
\hline $\mathrm{P} 1$ (forward) & ATGGCTGGACTATTGACCAC & CgmAChR-1 specific primer \\
\hline P2 (reverse) & TTATGTCTTATGACAGTCCAATCTC & CgmAChR-1 specific primer \\
\hline P3 (forward) & TTGAGAACGATGTATTAGAAGG & Real-time CgmAChR-1 primer \\
\hline P4 (reverse) & GTAGATACCTTCCCTCTCGCCG & Real-time CgmAChR-1 primer \\
\hline P5 (EF-RTF) & AGTCACCAAGGCTGCACAGAAAG & Real-time CgEF primer \\
\hline P6 (EF-RTR) & TCCGACGTATTTCTTTGCGATGT & Real-time CgEF primers \\
\hline P7 (forward) & CGCAATGGTCGCTTGGTGGTC & $\begin{array}{l}\text { Real-time } \\
\text { primer }\end{array}$ \\
\hline P8 (reverse) & CGTAGGGGCGGAAGGTCTCG & $\begin{array}{l}\text { Real-time } \\
\text { primer }\end{array}$ \\
\hline P9 (forward) & CAACGGTCTAACTTACCATCCAAAC & $\begin{array}{l}\text { Real-time TNF (CGI_10005110) } \\
\text { primer }\end{array}$ \\
\hline P10 (reverse) & TGGTGGTAGATAAAATGGGACAGTG & $\begin{array}{l}\begin{array}{l}\text { Real-time } \\
\text { primer }\end{array} \\
\text { TNF (CGI_10005110) }\end{array}$ \\
\hline P11 (forward) & ATTGGAGCACCTGGAGGATAAG & $\begin{array}{l}\text { Real-time TNF (CGI_10006440) } \\
\text { primer }\end{array}$ \\
\hline P12 (reverse) & CAGTCTTCCGTGCTGGTATTTC & $\begin{array}{l}\text { Real-time } \\
\text { primer }\end{array}$ \\
\hline M13-47 & CGCCAGGGTTTTCCCAGTCACGAC & pMD18-T simple vector primer \\
\hline RV-M & GAGCGGATAACAATTTCACACAGG & pMD18-T simple vector primer \\
\hline P13 (forward) & GGCCACGCGTCGACTAGTACT $_{17}$ & Oligo(dT)-adaptor \\
\hline
\end{tabular}

